\title{
Students' Evaluations of Profit and Utility of Higher Education: A Comparative Case Study
}

\author{
Davidovitch Nitza ${ }^{1, *}$, Lobova Elena ${ }^{2}$, Pryamikova Elena ${ }^{2}$, Semenova Tatiana $^{2}$, Pechenkina Tatiana ${ }^{2}, \&$ Yachmeneva \\ Maria $^{2}$ \\ ${ }^{1}$ Department of Behavioral Sciences, Ariel University Center of Samaria, Ariel 40700, Israel \\ ${ }^{2}$ Department of Sociology, The Ural State Pedagogical University, Russia \\ *Corresponding author: Ariel University Center of Samaria, Ariel 40700, Israel. \\ Tel: 972-3-9066103 E-mail: d.nitza@ariel.ac.il
}

Received: November 4, 2012

Accepted: December 5, $2012 \quad$ Online Published: January 17, 2013

doi:10.5430/wje.v3n1p23

URL: http://dx.doi.org/10.5430/wje.v3n1p23

\begin{abstract}
This paper reviews the recent turn toward a capitalist approach to higher education with specific reference to the social, demographic, and legislative changes, including growing academic capitalism, which led to a transformation in Israel's higher education system. In an empirical comparative case study of students from Israel and Russia, this study explores students' assessments of profit and utility of an academic education and its value in the respective local job markets. Findings confirm that students have adopted a capitalist approach to academic degrees, to which universities and colleges have responded by incorporating major changes and effectively instituting a paradigmatic shift in the roles and mission of higher education.
\end{abstract}

Keywords: academic capitalism; higher education; utility

\section{Students' Evaluations of Profit and Utility of Higher Education: A Comparative Case Study}

As an education system, higher education constitutes yet one more aspect of human beings' social existence. From a sociological perspective, the changes that affect higher education are part of a broad social context that finds further expression in the academic sphere. An examination of economic, political, social, legislative, and demographic changes allows us to view the changes in higher education as a reflection of sociological trends that are channeled into and shape the character of institutions of higher education.

\section{Massification of Higher Education}

From an economic perspective, the massification of higher education is the product of a barter economy that was subsequently transformed into a capitalist economy (Kogan \& Hanney, 2000). According to this economic ideology, changes in the nature of the economy led to the redefinition of the role of the individual, who became a potential producer of goods or services and tax payer to a state responsible for providing the tools and the authority to manage his productive operations. From this vantage point, education is a factor that enhances individual productivity and the state's indirect proceeds from it. This approach, which ties educational levels and monetary rewards and welfare, considers educated individuals as human capital (Amaral \& Magalhaes, 2004).

Viewing the education system as an economic tool is not new; this perspective is found at the foundation of the establishment of modern universities (Scott, 1995). Although this phenomenon is felt with increasing force in the twenty-first century, its roots can be traced to the late nineteenth century, which signaled the rise of capitalism and the transition to thinking in terms of profit and loss (Scott, 2006). Although research institutions have traditionally operated a policy of self-governance and remained aloof of the economic policy outside their walls, this economic approach penetrated academic institutions as well. As a result, considerations of financial gain, investments in entrepreneurs, patent drafting, collaboration with the industry, and managerial efficiency have become focal (Hoffman, 2011). The change in perspective and view of higher education as a means for economic growth and industrial development marked the paradigmatic change that created pressure on the universities to produce 
outcomes. If in the past, the academia had been outside the business world, engaged in its own affairs at the margins of the social world, in the twentieth century, the academia's role changed significantly. Suddenly it was required to train qualified professionals, conduct applied research projects, and play an important role in the nation's progress. As a result, the academia was forced to transition to the large-scale preparation of citizens' mission for life in an advanced industrial society, and to shift its educational emphasis from a formative impact on students' character and world, to instruction of specific skills and occupational training, and to define the goals and targets that are expected of graduates in terms of the academic "outcomes" that should be produced (Yadgar, 2007). Moreover, the academia was also required to target new, weaker population groups (Ivri, 2007). Academic capitalism creates several challenges for universities, including the challenge of recruiting academic scholars who are qualified in commercial operations, and the challenge of prioritizing academic studies based on their profit potential (Hoffman, 2011). Ira (2007) also pointed to universities' need to attain a balance between the previous full public funding, to the current situation, in which openness and creativity are necessary in order to generate economic security.

The economic changes that occurred primarily in response to the change in perspective and the view of academia as a capitalist institution were only part of a broad range of changes, including political, social, legislative, and demographic changes that led to the global growth of higher education (Levy, 2001):

\section{Socio-Political Change}

Until the early twentieth century, higher education institutions in western societies were instrumental in training political and social elites. In the early twentieth century, with the establishment of the welfare state and the development of certification procedures, the state began to recognize the need and its obligation to direct resources to expand higher education. According to the theory proposed by Meir and Melamed (2005), the development of educational systems is the result of the reorganization of modern society on the basis of secular individualism. This organizational process included the establishment of a system legitimizing knowledge and professional faculty. According to this approach, state support of the academia is based on the need for expert professionals, and the universities are instrumental in training individuals of knowledge and authority.

In his study, Yogev (1992) reviews three theoretical perspectives for understanding social structure and the stimuli for the expansion of higher education. According to the first perspective, which is based on practical-systemic interpretations, the driving force of this development is the need for individuals with expertise. The second perspective stresses systemic explanations as the driving force, specifically the transition to nation state systems. The third explanation is rooted in Marxist social conflict theory. According to this approach, the expansion of higher education is the outcome of the conflict created by the division of society into classes with different interests. Conflicts of interest create social conflict in which each group wishes to realize its own goals. Opening the gates of higher education institutions to the masses can be considered a solution to this conflict, since education is the means of achieving social mobility.

These social and political changes were born of necessity in Israel, signatory to the International Covenant on Economic Social and Cultural Rights (ICESCR). This international treaty focuses on the principle of equal access, which demands that the state develop and maintain a system of higher education in which admission is based exclusively on applicants' individual scholastic merit rather than on group characteristics such as economic situation, or cultural, sectorial, or national membership.

Changes were also triggered by the rising power of the new right and neoliberalism, which called for a redesign of public services in general and of education in particular, by market forces (Volensky, 2005). Legislative changes proceeded hand in hand with the socio-political changes.

\section{Legislative Change}

Several laws were enacted in Israel that facilitated increased access for various population groups, including Government Resolution 3694 adopted in 1994, in which the government resolved to increase the number of institutions certified to award academic degrees. At the same time, the law permitted the operation of nonfunded academic institutions and the establishment of extensions of foreign universities in Israel (Berenstein, 2002). In 1995, Amendment 10 to the Higher Education Law was enacted, bringing the colleges into the higher education system and determining that colleges would also be allowed to award academic degrees. Demographic changes in Israel also had a significant impact on the process of massification. 


\section{Demographic Change}

The demographic changes that occurred in Israel included an absolute increase in the population of 18-year-olds, an increase in the number of individuals entitled to receive a matriculation certificate, changes in preferred subjects, and an increased demand for professional-type studies (Planning and Budget Committee, 2003). There was also an influx of large waves of immigration from the former Soviet Union, who had expectations of continuing to higher education (Lev Zion, 2000).

These economic, socio-political, legislative, and demographic changes led to demands to open the gates of higher education institutions to populations that had previously been excluded from these educational settings. The colleges and universities recognized the potential that these changes offered, and as newly capitalist institutions, they began to develop new programs, new curricula, new study tracks, offer flexible schedules and apply more lenient admission criteria, develop structured programs for specific target populations, develop interdisciplinary programs in faculties and involving more than one faculty, offer organizational development programs to specific corporate clients, as well as other changes.

The response was not late in coming. In 1990, the number of students in higher education was 90,951, but by 2011 245,719 students were attending some type of higher education institution (Central Bureau of Statistics, 2011): The higher education system became accessible to diverse populations. Access implies an elimination of barriers in order to allow unfettered access to a specific target. The research literature identifies three types of barriers to acquisition of higher education: barriers stemming from the socio-cultural context, barriers related to the institutions and the program, and individual barriers of candidates (Rogers, 2000). According to Shay (1996), these barriers are rooted in three public components: the system's willingness to absorb potential students; access to information on possible study options; and the conditions that must be met to achieve an education, in terms of all the (academic, economic, environmental, and social) obstacles that apply to each student.

Opening the gates of higher education and increasing access to higher education for students of diverse social strata and diverse intellectual aptitudes has transformed the Bachelor's degree into a "degree of the masses" in what is known in the research literature as the "massification" of higher education. Massification implies a shift from a limited, elitist system to a system designed for the masses (Trow, 2003).

\section{Massification Infiltrates Graduate Degree Programs}

The process of massification in Israel's system of higher education created a series of challenges and problems for the academia. One of the prominent changes was in the area of academic administration and internal governance. Massification and the transition to a universal system affected institutions' internal operating procedures: The rise in the number of students led to a need to expand the academic faculty and administrative staff; the entire system expanded and was required to operate according to management methods that suited large-scale organizations; the institutions came under powerful pressure to provide financial reports and employ professionals; the change in human resources, together with the administrative changes, created a need to report outcomes, profits, and benefits.

In addition to the administrative changes, changes occurred also in curricula and teaching methods. The transition to a system oriented toward professional training for large numbers of students triggered the need to modify curricula. According to the traditional method, structured curricula with a broad horizon were designed to cultivate educated, liberal individuals. In education for the masses, the tendency is to develop a succession of semi-structured courses with credits, flexibility, and accessibility in transferring between programs and institutions. Furthermore, instruction that suited large numbers was prioritized, in contrast to the individual mentoring approach of the past (Yadgar, 2007).

Changes in institutional boundaries and criteria also changed - from a restricted system for the elites, characterized by a high uniform standard, the system has become diverse. The criterion of achievement has changed from academic value to the value of educational experience. Changes in standards and quality and the transition to a mass community also changed institutional boundaries. Institutions which were previously islands of elitist knowledge within society became integrated into society (due to the high proportion of society members involved in the institutions). The ivory towers of the past became the playing field of the general public, obliterating institutional boundaries.

Another change that occurred involved the centers of power and decision making. In the past, universities were small institutions that were managed by small groups elected from within. These groups had identical interests. They were an elite group that guided the academic institutions based on a consensus on academic, political, and economic issues. 
The expansion of the system and the transition to large numbers of students forced the closed world of the academia to communicate with the external environment. Elite groups are still in charge of decision making in the system, but they are largely subject to external influence. The political and even market forces, which were alien to the world of academia, became relevant considerations.

The environmental changes and changes in the education system contributed to the growing massification of advanced degrees as well, which developed as the direct result of three main factors: Similar changes occurring in Europe and the United States; changes in the framework of master-degree programs in response to decision makers in colleges and universities who began to think in capitalist terms; growing pressure on the part of employers and graduates of the higher education system to introduce changes to respond to these demands.

Johns Hopkins University, founded in 1876, signifies for many the beginning of graduate studies in the United States (Altbach, Berdahl, \& Gumport, 2005). The founder of this institution designated it for students who would devote all their time to research in specific fields. At the conclusion of their studies, students were awarded a $\mathrm{PhD}$. In time, the American Association of Universities (AAU), whose founding members included Johns Hopkins, Harvard, and Yale, believed that a new graduate program was needed. The new program included an intermediate degree - a master's degree - on the route to a doctorate degree, which became the highest criterion in the hierarchy of degrees, and a master's degree became a milestone in one's research-oriented career. In 1909, the AAU defined the purpose of graduate studies as a research degree whose purpose was enrichment (ASHE Higher Education Report, 2005).

The United States, the first country to label graduate studies as such, experienced an expansion and rise in the number of students eligible for a graduate degree. Between 1969 and 2004, the number of individuals who entered graduate programs increased by 1.2 million (AUCC, 2002). Statistics show that in recent years, the population of graduate school candidates has become older, more diverse, and constituting a greater share of the labor market, compared to the 1980s (Choy \& Geis, 2002; Vedder, 2011). It has been argued that these trends not only point to the new mission of graduate study programs, but also to a new direction in the knowledge creation process (ASHE Higher Education Report, 2005).

In a doctorate thesis creatively entitled "The person next to you on the bus probably has a graduate degree," Smith (2008) investigated the expansion of graduate degrees in the United States and replicated the parameters that had previously been used by Trow (1973) to examine the expansion of undergraduate degrees. Smith's study indicated that the higher education system that awards graduate degrees in the United States had become a mass system in 1987; today, slightly less than $20 \%$ of the relevant age group are graduate students. She also found no significant correlation between the upward trend in undergraduate degrees and the increase in graduate degrees, both in terms of relative and absolute growth.

Massification also occurred in Europe. Initially, the higher education model was constructed along the lines of the preliminary German model, which included six years of study at the end of which the student is eligible for a master's degree. This structure created a series of problems that increased as higher education expanded. The length of the program, the required government investment, the relatively advanced age at which graduates enter the job market (Stallmann, 2002) all highlighted the need for a new, modular, and more flexible model that would suit the rapidly changing global world. In 1999, the Bologna Declaration announced the principles for creating a European space of higher education including a common structure of degrees (and similar program length), and a European system of accreditation based on credits acquired in courses in various countries. One of the outcomes of this agreement was the cancellation of the diploma degree and its replacement with the Ango-Saxon terms: undergraduate and graduate degrees (Lindblom-Ylänne\& Hämäläinen, 2004).

A study by Cardoso et al. (2008) explored the effect of the Bologna Declaration on the demand for higher education in Europe. Findings of this study show that the Declaration has a positive impact on the demand for higher education in general. The transition to a tertiary system did not diminish the demand for graduate degree programs. On the contrary, more students continue their studies after completing a graduate program. Following the Bologna Declaration, most countries in the world adopted the tertiary system of higher education. Israel, as a part of the postmodern western world, has also been part of this process since the $1950 \mathrm{~s}$.

\section{Motives for Higher Education}

In the literature, researchers have identified two types of motives for higher education: extrinsic motives (such as career and income) and intrinsic motives related to the learning process (such as interest and understanding) (Dippelhofer-Stiem et al., 1984; Hayden \& Carpenter 1990). Greene and Minton (1989), also US-based researchers, 
discuss educational, professional motives and career aspirations. Windolf (1995) note career aspirations (higher education, professional advancement, prestige, and security), interest in science and scientific research, scientific theories and insights into the field of study, as well as lifestyle considerations (the desire to experience student life, political activism, and to influence change and help others). Canny (1995) lists occupational factors (preparing for a career and finding a good job), academic factors (intellectual growth and expanding education), and social factors (meeting new people, having a good time, access to sports facilities). In the Israeli context, Shapira and Etzion-Halevi (1973) distinguished between education-related motives (viewing education as a goal), instrumental motives (career training, professional or status advancement), and social motives (potential social life and entertainment). Doron (1983) lists seven motives: education, career, self-realization, family, personal professional advancement, income, and social. Similar extrinsic and intrinsic motives have been identified in other countries and at different times. The current study focuses on three motives:

Intrinsic motives: (1) Investigative motives - to gain knowledge, broaden one's horizons, clarify values and opinions, deepen self-understanding; (2) Self-realization - need for achievement, motivation for learning, and realization of talents and aptitudes.

Extrinsic motives: (3) Instrumental motives - to acquire a profession, attain a degree and diploma, develop a career, and increase one's income.

The first group of motives is related to the individual's internal motivations. Through learning, the individual realizes her need for achievement, which is defined as the urge to succeed and cope successfully with the challenges that one sets for oneself. This is the motive that pushes the individual to ever-greater achievements in any field, based on the sense of satisfaction, realization, and challenge. Individuals motivated by a need for achievement set challenges for themselves and aspire to perform related tasks (in education, in work, and in other fields) to the best of their ability, in order to achieve the sense of satisfaction generated by the knowledge that they overcame obstacles and achieved their goals.

All individuals have some degree of motivation that propels them toward achievements, although individuals differ in the degree in which they are willing to invest resources for the goals they set themselves. Individuals with a high need for achievement are willing to invest time and effort and to persevere in order to achieve their goals, while individuals with a low need for achievement invest less time and effort, persevere less, and tend to withdraw in the face of failure (Bar-El \& Nuemayer, 1996). Today, scholars concur that the need for achievement is affected by environmental factors and primarily by an individual's learning style in childhood. As children, individuals with a high need for achievement had parents who encouraged them and supported them even when they failed.

Numerous studies address the factors that affect motivation, especially the motivation for learning achievements. Studies point to diverse factors that cause pupils to learn, including selection of the study material, degree of effort and perseverance required, and preference of a specific learning method. Motivations for learning determine a general direction, but the specific choice of a program depends on various variables including family support, social support, individual resources, and scholastic achievements.

\section{Credentialism}

Credentialism, defined by Dore (1976) as the emphasis placed by students or employers and the tendency to place greater value on a diploma than on the aptitudes themselves, creates a vicious circle that requires increasingly advanced degrees to compensate for a diploma's diminishing value. This process occurs mainly due to employers' belief that education "improves" employees and by employing individuals with a more advanced degree than necessary, employers receive more value for their money. This belief leads employers to demand undergraduate and graduate degrees of employees, a process termed credentialism by Brown (2001).

Tyler (1982) argued, based on the human capital theory, that employers use accreditation as a selection factor that they consider a quasi-predictor of employee efficiency and productivity. Education is considered a factor that increases individual productivity and the indirect income of the state. This approach views the educated individual as human capital by connecting educational levels and financial remuneration and welfare (Amaral \& Magaihaes, 2004).

Brown (2001) explains credentialism by stating that in a bureaucratic world, accreditation conveys information about an individual's ability to perform tasks according to the required bureaucracy. Possessing an academic degree represents "something else", something more significant in the job market, such as knowledge, skills, and loyalty. According to this explanation, the market needs degrees because degrees are considered critical in assessing 
employee aptitudes, even if these are not directly required for the job. The fact that academic degrees have become indices of ability is explained by Bills (1988a) who argued that academic degrees have become a kind of occupational asset.

While employers use degrees to create a division of jobs, employees view advanced degrees as a means of increasing personal profit. Studies have confirmed this approach and the view of education as a means of achieving economic security and protection against poverty (Vedder, 2011; Vernon, 2010). For students, acquiring a profession and a diploma allows them to increase their economic value in the job market. Employees consider undergraduate degrees as representing future economic income. Wonacott (2000) stated, “...Bachelor's degree is widely considered the universal ticket to a desirable, high-paying career and comfortable middleclass life" (p. 1); this is even more applicable for graduate degrees.

\section{Method}

The current study is a follow-up study to research conducted in 2011, a joint initiative of researchers from the Ekaterinburg University of the Ural and the Ariel University Center in Israel, as part of the scientific collaboration between the two institutions. Students at both institutions participated in the study. The topics of the study were determined by the researchers, based on their understanding of the significance of growing globalization in the world of higher education, and the consequent significance of intercultural research on higher education. It has been argued that cultural differences among students significantly influence students' learning expectations, habits, and preferences. In this study, we wished to examine a series of differences in learning style, expectations, and learning habits of Israeli students compared to Russian students. The questionnaire that was developed for this study includes 44 items on the following fields: background details and previous studies, attitudes to higher education and the perceived potential of higher education, assessments of the learning environment, and the responsibility of students and instructors in the learning process.

\section{Findings}

\subsection{Background and Academic Background}

Population profiles. The samples from Russia and Israel differ: The Israeli sample includes no medical students, while the Russian sample comprises primarily medical students. The Israeli sample has a balanced gender composition, while the Russian sample comprises a majority of male students. The Russian students are, on average six years younger than the Israeli students. In view of these differences, the differences that emerge in the following findings may be traced to differences in the profiles of the two populations.

Work experience. The Russian sample includes a higher proportion of students with no work experience at all, compared to the Israeli sample. In both groups, one-fifth of the students in both groups report having experience in the field that they are studying.

Academic achievements. Close to one half of the Israeli sample report high academic achievements (a grade average of 85 or higher) and only $10 \%$ of the Russian sample report similar achievements. On the other hand, the Israeli sample contains very few students with extremely low grades, while one third of the Russian sample report very low grades. These differences may stem from differences in the aptitudes of students in both groups or from the different use of the grading scales in the two countries.

\subsection{Perceptions of Higher Education and its Potential}

The significance of opportunities created by higher education. For both groups, education is important in preparing to acquire a profession for the future and to develop a career. In Russia, however, students believe that education plays an important role in developing personal traits and skills and offers students the opportunity to become educated, intellectual individuals. One fifth of the Russian respondents also view academic education as an opportunity to meet new people. This dimension is hardly mentioned by the Israeli sample.

Plans after graduating from the undergraduate program. Both groups have similar plans for after graduation, although a greater proportion of Israeli students would like to continue to graduate programs while a greater proportion of Russian students intend to work in a field that is unrelated to their studies.

Perceived chances for the future after graduation. Russian students are more optimistic about their future after graduation: $40 \%$ believe that they will easily find employment, compared to a mere $16 \%$ of the Israeli sample. One 
quarter of the Russian sample, but a much smaller proportion of the Israeli sample, believe that they can manage the work of other experts or engage in scientific research.

Assessing the chances of finding a job after graduation. Although more Russian students believe that they will easily find a job after graduation, both groups share a similar assessment of the chances of finding a job in their field of study. Approximately one half are confident that they will find a job in their field, while one fifth believe that it will take them a long time to find a job in their field of study.

\section{Discussion}

The academia and its tasks have undergone a series of changes and revolutions over the centuries since its foundation: social, economic, political, and technological changes have left their mark on the various tasks assigned to the academia - professional training, civil service, research, teaching, moral education, and community service. The evolution of these tasks reflects the dynamic nature of the interactions involving the academia and its environment. Israeli academia, despite its short history, was also affected by changes related to its declared mission: from higher education for its own sake to professional training; from a view of education as the goal, to a view of education as a means; from the value of learning for its own sake, expanding knowledge, exploration and discovery - to technological studies and applied science; from a value of excellence in learning to learning whose prominent value is equality for all.

The findings of this study indicate that students' thoughts, perceptions, and orientation focus on employment. Employment is the practical value that they seek, while their studies are merely the means of achieving this value. These findings are evidence of the increasingly strong paradigmatic change, which reflects the transformation of higher education into a means rather than an end unto itself.

The question is whether this orientation will have an impact on academic institutions, which are directed at discovery, exploration, and extending knowledge, beyond the daily needs of human existence. To what degree, if any, will occupational considerations become incorporated as integral elements in study disciplines, in the form of practical training or field observations or ties with potential places of employment? To what degree, if any, will the practical aspects of academic education and the capitalist approach of profit and loss eclipse academic exceptionalism and academic demands in higher education? To what degree are academic institutions committed to working on behalf of students? Are students' expectations regarding future employment realistic?

It appears that the higher education system is trying to speak in both voices: on the one hand, the academic system conducts itself apart from the field. Its main challenges and missions are research, discovery, and innovation, which go beyond everyday practicalities. On the other hand, there would be no academia or academic instruction without students. Since the academic system needs students, it makes an attempt to respond to students' needs in several fields, by bringing discovery into the field, as one of the targets of academic instruction and community service. The question is the proportion of these voices needed to ensure that the academia does not sink into the field and instead maintains its goals, without which it would betray its primary purpose.

\section{References}

Altbach, P. G. (2005). Patterns in Higher Education In P. G. Altbach, R. O. Berdahl, and P. J. Gumport (Eds.) Development in America higher education in the 21st century: Social, political and economic challenges (pp. 15-37). Baltimore and London: The Johns Hopkins University Press.

Amaral, A., \& Magalhaes, A. (2004). Epidemiology and the Bologna saga. Higher Education, 48, 79-100. http://dx.doi.org/10.1023/B:HIGH.0000033766.02802.92

ASHE Higher Education Report, (2005). Conceptualizing the Master's Degree. ASHE Higher Education Report, 31(4), 1-4. Retrieved from Academic Search Premier Database.

Association of Universities and Colleges of Canada (2002). Trends in higher education. Ottawa: AUCC.

Bar-El, A., \& Nuemayer, M. (1996). Encounters with psychology (2nd ed.). Tel Aviv: Rechess.

Berenstein, S. (2002). The rise and fall of private higher education in Israel. Mehkarei Mediniyut, 52, 1-42. [Hebrew]

Bills, D. B. (1988). Credentials and capacities: Employers' perceptions of the acquisition of skills. The Sociological Quarterly, 29(3), 439-449. http://dx.doi.org/10.1111/j.1533-8525.1988.tb01263.x 
Brown D. K. (2001). The social sources of educational credentialism: Status cultures, labor markets, and organizations. Sociology of Education, 74, Extra Issue: Current of Thought: Sociology of Education at the Dawn of the 21st Century, 19-34 .

Canny A. (1995). School-leavers' career choices: An Investigation of the relationship between action and structure. Irish Journal of Sociology, 5, 164-191.

Cardoso, A., Portela, M., Sá, C., \& Alexandre, F. (2008). Demand for higher education programs: The impact of the Bologna process. CESifo Economic Studies, 54(2), 229-247. Retrieved from SocINDEX with Full Text database. http://dx.doi.org/10.1093/cesifo/ifn013

CBS (2011). Higher education in Israel - Press release for the occasion of the beginning of the 2011/2012 academic year. Jerusalem: 293/2011. (in Hebrew)

Choy, S. P., \& Geis, S. (2000). Student financing of graduate and first-professional education 1999-2000. Education Statistics Quarterly, 4(3), 1-6.

Dippelhofer-Stiem, T., Bargel, B., Bromberek, E., Jetten, S., Kump, G., Sagmeister, H.-G., \& Walter, J. T. (1984). Students in Europe, motives for studying, expectations of higher education and the relevance of career prospects. European Journal of Education, 19, 309-315. http://dx.doi.org/10.2307/1502848

Dore, R. (1976). The diploma disease. Berkley and Los Angeles: University of California Press.

Doron, N. (1983). On the road to success. Tel Aviv: Yahdav. [Hebrew]

Greene, H., \& Minton, R. (1989). Beyond the ivy wall: 10 essential steps to graduate school admission. Boston: Little Brown \& Company.

Hayden, M., \& Carpenter, P. G. (1990). From school to higher education in Australia. Higher Education, 20(2), 175-196. http://dx.doi.org/10.1007/BF00143700

Hoffman, A. J. (2011). Thirty-five years of research on business and the natural environment. Part 1: A statistical synopsis. Retrieved from http://oneaomonline.blogspot.com/2011/07/thirty-five-years-of-research-on.html

Ivri, Y. (2007). Facing the periphery. Position paper on representation of students from the periphery at the Hebrew University. Jerusalem: Mendel Institute of Leadership.

Kogan, M., \& Hanney, S. (2000). Reforming higher education. London: Jessica Kingsley Publishers.

Lev Zion, N. (2000, June). The revolution in higher education in Israel: Budgeting policy of higher education institutions in the next decade. Position paper presented at Maariv Conference. Tel Aviv. [Hebrew]

Levy, B. R. (2001). Eradication of ageism requires addressing the enemy within. Gerontologist, 41, 578-579. http://dx.doi.org/10.1093/geront/41.5.578

Lindblom-Ylänne, S., \& Hämäläinen, K. (2004). The Bologna Declaration as a tool to enhance learning and instruction at the University of Helsinki. International Journal for Academic Development, 9(2), 153-165. http://dx.doi.org/10.1080/1360144042000334645

Meir, E. I., \& Melamed, S. (2005). Occupational specialty congruence: New data and future directions. Journal of Vocational Behavior, 67, 21-34. http://dx.doi.org/10.1016/j.jvb.2004.05.007

Planning and Budget Committee (2003). Data on the higher education system. In Commission for Higher Education. Report No, 28/29 for 2000/1 and 2001/2. Jerusalem.

Rogers, D. L. (2000). A paradigm shift: Technology integration for higher education in the new millennium. Educational Technology Review, 20, 19-33.

Scott, J. (2006). The mission of the university: medieval to postmodern transformations. Journal of Higher Education, 77, 1-39. http://dx.doi.org/10.1353/jhe.2006.0007

Scott, P. (1995). The meanings of mass higher education. England: Bury St. Edmunds, SRHE and The Open University Press.

Shapira, R., \& Etzioni, E. (1973). Who is the Israeli student? Tel Aviv: Sifriyat Ofakim, Am Oved. [Hebrew]

Shay, S. (1996). Access to higher education: Public positions, Stage B. Jerusalem: Guttman Institute of Applied Social Research. [Hebrew]

Smith, C. (2008). The person next to you on the bus probably has a graduate degree too: a study of the expansion of 
graduate education. Dissertation submitted to the University at Albany, State University of New York. School of Education Educational Administration and Policy Studies.

Stallmann, F. (2002). A student's perspective on the introduction of the bachelor's and master's degree in German higher education. German Policy Studies/Politikfeldanalyse, 2(3). Retrieved from Academic Search Premier database.

The ASHE Higher Education Report (2005).

Trow, M. (1973). Problems in the transition from elite to mass higher education. Berkeley, California: Carnegie Commission on Higher Education.

Trow, M. (2003). In praise of weakness: Chartering, the University of the United States, and Dartmouth College. Higher Education Policy, 16, 9-26. http://dx.doi.org/10.1057/palgrave.hep.8300000

Tyler, W. (1982). Complexity and control: The organisational background of credentialism. British Journal of Sociology of Education, 3(2), 160-170. http://dx.doi.org/10.1080/0142569820030204

Vedder, R. (2011, January 5). Too many PhDs and professionals? The Chronicle of Higher Education. Retrieved from https://chronicle.com/blogs/innovations/too-many-ph-d-\%E2\%80\%99s-and-professionals/28236

Vernon, J. (2010, October 22). Disaster strikes: The end of the public university in England. Universities in Crisis Blog of International Sociological Association (ISA). [Blog post] Retrieved from http://www.isa-sociology.org/universities-in-crisis/?p=774

Volansky, A. (2005). Academia in a changing environment. Shmuel Neeman Institute and Hakibbutz Hameuhad. Tel Aviv. [Hebrew]

Windolf, P. (1995). Selection and self-selection at German mass universities. Oxford Review of Education, 21(2), 207-31. http://dx.doi.org/10.1080/0305498950210206

Wonacott, M. E. (2000). Credentials: One size fits all? Columbus, OH: National Dissemination Center for Career and Technical Education. ED 447275.

Yadgar, A. (2007). Crisis and change in higher education and how research universities in Israel cope. Tel Aviv.

Yogev, A. (1992). Educational expansion in the world and in Israel and its social implications, in A. Yogev (Ed.) Educational expansion in Israel, Series for education and social issues. Tel Aviv: Massada and Tel Aviv University. [Hebrew] 